\title{
Waqf Administration in India: Issues and Challenges of State Waqf Boards
}

\author{
Tabasum Rasool \\ Department of Political Science, \\ Aligarh Muslim University, Aligarh, India
}

\begin{abstract}
The law (Waqf Legislation) in India conceptualizes waqf as 'the permanent dedication by any person, of any movable or immovable property for any purpose recognised by the Muslim law as pious, religious or charitable.' The theoretical implication of creating a waqf suggests that the said property can never again change hands by inheritance, sale or seizure. The report on social, economic and educational status of Muslim community of India (2006) popularly known as "Sachar Committee Report" estimated that there are more than 4.9 lac registered waqfs in India. The total area under these properties is estimated at about six lac acres. Apart from agricultural, commercial and residential properties, waqf in India include functional/non-functional mosques, $\operatorname{darghās~(tomb~or~shrine~of~Muslim~saint),~}$ khanqahās (building or space for Sufi brotherhood) maqbaras (tombs), ashoorkhanās (mourning place for Shias), qabristāns (graveyards), idghās (space to offer Eid Prayer), imam-baras (space for prayers and gatherings for Shias) etc. But due to political apathy, encroachment, poor governance and insensitiveness of society, it has not fully survived the test of its purpose. Auqāf is meant to create a welfare and just society- a society which does not leave anybody to die hungry and ignorant. This paper will investigate the problems of waqf administration in India with a focus on the functioning of state waqf boards.
\end{abstract}

Keywords: Waqf, Waqf board, Indian Muslims, governance, Scahar Committee Report

\section{Introduction}

The law (Waqf Legislation) ${ }^{1}$ in India conceptualizes waqf as 'the permanent dedication by any person, of any movable or immovable property for any purpose recognised by the Muslim law as pious, religious or charitable.' ${ }^{2}$ And in Islamic Law

\footnotetext{
${ }^{1}$ For the better administration of waqf properties in the country, Government of India passed the Waqf Act 1954. Before it was repealed and replaced by the Waqf Act 1995, the Waqf Act 1954 was amended in 1959, 1964, 1969 and 1984. Presently waqf adminidtration in India is governed by the Waqf Act 1995 which was amended by the Waqf (Amendment) Act 2013.The Waqf Amendment Act 2013 was repealed by Repealing and Amending (Second) Act, 2015. It however does not nullify the amendments made by Waqf (Amendment) Act 2013 to Waqf Act 1995. Therefore, wherever Waqf Act is mentioned, it means Waqf Act 1995 as amended by Waqf (Amendment) Act 2013.

${ }^{2}$ Section 3(r) of waqf Act reads "waqf" means the permanent dedication by any person, of any movable or immovable property for any purpose recognised by the Muslim law as pious, religious or charitable and includes - (i) a waqf by user but such waqf shall not cease to be a waqf by reason only of the user having ceased irrespective of the period of such cesser; (ii) a Shamlat Patti, Shamlat
} 


\section{.}

a waqf property is permanently dedicated to Allah Almighty and is to be used, as specified by the Waqif for permissible purposes. ${ }^{3}$ Monzer Kahf defined waqf as "holding a Maal (an asset) and preventing its consumption for the purpose of repeatedly extracting its usufruct for the benefit of an objective representing righteousness/philanthropy." "The theoretical implication of creating a waqf suggests that the said property can never again change hands by inheritance, sale or seizure. ${ }^{5}$ It is perpetual, inalienable and irrevocable in nature. On the issue of ownership, there is consensus of the Ummah that it vests in Allah Almighty and is incapable of human ownership. ${ }^{6}$ Since Allah Almighty is not a physically tangible entity the community is considered to be the actual heir of auqāf (plural of waqf) and through appointed Mutawalli (trustee of waqf) controls its affairs. ${ }^{7}$ Hence waqf becomes a public property that cannot be given away, sold, mortgaged, inherited or otherwise disposed of. When the specified purposes cease, the relief of the poor is the ultimate purpose of every waqf. ${ }^{8}$ Wäqif is the person who makes waqf and Mutawalli stands for the person appointed by $W \bar{a} q i f$ for managing or administering a waqf.

Apart from agricultural, commercial and residential properties, waqf in India include functional/non-functional mosques, darghās (tomb or shrine of Muslim saint), khanqahās (building or space for Sufi brotherhood) maqbaras (tombs), ashoor-khanās (mourning place for Shias), qabristāns (graveyards), idghās (space to offer Eid Prayer), imam-baras (space for prayers and gatherings for Shias) etc. The report on social, economic and educational status of Muslim community of India (2006) popularly known as "Sachar Committee Report" estimated that there are more

Deh, Jumla Malkaan or by any other name entered in a revenue record; (iii) "grants," including mashrat-ul-khidmat for any purpose recognized by the Muslim law as pious, religious or charitable; and (iv) a waqf-alal-aulad to the extent to which the property is dedicated for any purpose recognized by Muslim law as pious, religious or charitable, provided when the line of succession fails, the income of the waqf shall be spent for education, development, welfare and such other purposes as recognized by Muslim law.

${ }^{3}$ Qazi Mujahidul Islam Qasmi, Auqāf: Ahkam-o-Masa'il (New Delhi: Ifa Publications, 2012), 129.

${ }^{4}$ Monzer Kahf, "Financing the Development of Awqaf Property," The American Journal of Islamic Social Sciences, 16 (Winter 1999): 4, 41.

${ }^{5}$ Gregory C. Kozlowski, Muslim Endowments and Society in British India (London: Cambridge University Press, 1985), 1.

${ }^{6}$ Qazi Mujahidul Islam Qasmi, Auqāf: Ahkam-o-Masa'il (New Delhi, 2002, Reprint. Ifa Publications, 2012), 7.

${ }^{7}$ Hilal Ahmed, Muslim Political Discourse in post-colonial India: Monuments, Memory, Contestations (New Delhi: Routledge, 2014), 37.

${ }^{8}$ Mohd. Zain bin Haji Othman, Islamic Law with Special Reference to the Institution of Waqf (Kuala Lumpur: Prime Minister's Department, 1982) quoted in Khoo Salma Nasution, “Colonial Intervention and Transformation of Muslim Waqf Settlements in Urban Penang: The Role of the Endowments Board," in Journal of Muslim Minority Affairs, 22:2 (2012): 299-315, DOI:10.1080/1360200022000028112. 


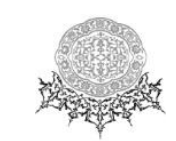

than 4.9 lac registered waqfs in India.The total area under these properties is estimated at about six lac acres with book value at about 6,000 crores. Since the book value is about half a century old the current value will be several times more and market value has been estimated at 1.2 lacs crores. The report further reveals that the annual income from these properties is only about 163 crores which amounts to $2.7 \%$ of book value. If these properties are put to efficient and marketable use they can generate at least a minimum return of 10 per cent which is about Rs (rupees - Indian Currency) 12,000 crores per annum and the income so generated can be used to improve the socio-economic and educational status of Indian Muslims. ${ }^{9}$ But due to political apathy, encroachment, poor governance and insensitiveness of society it has not fully survived the test of its purpose. Auqā $f$ is meant to create a welfare and just society which does not leave anybody to die hungry and ignorant.

\section{Waqf Administration in India}

Traditionally waqf properties were individually administered by Mutawallis who were supervised by Qadhis (magistrate/judge of Shari 'ah Court) and the same practice continued during the reign of the Muslim kings in India. The British initially continued the same administrative structure but discontinued the policy in $1810 .{ }^{10}$ Many efforts were made through legislation ${ }^{11}$ for the administration of auqā $f$ during the British rule. Some issues and demands of Muslims were addressed and most remained neglected.

Government of India passed the Waqf Act 1954 with an aim of better administration of waqf properties in the country. The Waqf Act 1954 was amended in 1959, 1964, 1969 and 1984 and finally was repealed and replaced by the Waqf Act 1995. At present waqf administration in India is governed by the Waqf Act 1995 which was amended by the Waqf Amendment Act 2013. The Act is divided into 9 chapters with 113 sections.

The auqāf in India comes under the Ministry of Minority Affairs. ${ }^{12}$ The Minister of Minority Affairs is ex-officio Chairman of Central Waqf Council which

\footnotetext{
${ }^{9}$ Government of India, Social, Economic and Educational status of Muslim Community of India, Report (New Delhi: Cabinet Secretariat, 2006), 219.

${ }^{10}$ The Regulation 111 of 1810 of Bengal Code and Regulation V11 of 1817 of Madras Code, Board of Revenue or Board of Commissioners of these two provinces were given the general superintendence of all endowments including Auqäf. With the enactment of the Religious Endowments Act, 1863 the practice was abandoned and local committees functioned as new custodians of Auqāf. In 1864 the Kazees Act abolished the institution of Qadhi and left waqf to be addressed by English Judges who applied English legal principles instead of Shari 'ah.

${ }^{11}$ See The Musalman Waqf Act, 1923; The Bengal waqf Act, 1934; The Musalman Waqf (Bombay Amendment) Act, 1935; The United Provinces Muslim Waqf Act, 1936; and The Delhi Muslim Waqf Act, 1943.

${ }^{12}$ Prior to the establishment of the Ministry of Minority Affairs on $29^{\text {th }}$ January 2006, waqf was allotted to the Ministry of Social Justice and Empowerment.
} 


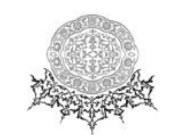

is a statutory body established in 1964 under the provision of section 8 (a) of Waqf Act 1954 (now section 9 (1) of Waqf Act 1995) for the purpose of advising the Central Government, the State government and the State Waqf Boards on the administration of auqāf. The basic unit in waqf administration is Mutawalli. ${ }^{13}$ State Waqf Boards are to ensure that the auqāf are 'properly maintained, controlled and administered and the income thereof is dully applied to the objects and for the purpose for which such auqa $\bar{f}$ were created or intended. ${ }^{14}$ Mutawallis have to pay $7 \%$ of their net annual income towards their respective Boards. ${ }^{15}$ The StateWaqf Boards shall pay $1 \%$ of the net annual income to Central Waqf Council. ${ }^{16}$

\section{Waqf Boards}

Under the Waqf Act, the State Waqf Boards are established by respective State governments ${ }^{17}$ for the general superintendence of all waqfs in a State ${ }^{18}$ with five years as a term of office. ${ }^{19}$ If the number or income of Shia waqf properties in a State is more than fifteen per cent, a separate Waqf Board for Shias may be established. ${ }^{20}$ The Board is a body corporate having perpetual succession and a common seal with power to acquire, hold and transfer property and can sue and be sued. ${ }^{21}$ The Board is composed of both elected and nominated members. The State Government elects one and not more than two members from each of the electoral colleges consisting of Muslim members of Parliament, State Legislature, Bar Council and Mutawallis. The State Government also nominates one person among Muslims, having professional experience in town planning, business management, social work, finance, revenue, agricultural and development activities. Also, one Muslim recognised scholar of Shia and Sunni theology and one Muslim officers of the State Government not below the rank of Joint Secretary to the State Government. In case of Union territories other than National Capital Territory of Delhi, the Board should consist of not less than five and not more than seven members to be appointed by the Central Government. Every Board shall have at least two women members. ${ }^{22}$

\footnotetext{
${ }^{13}$ Historically Mutawalli used to be the main and primary institution governing auqāf. After partition most of the Mutawallis in northern Indian migrated to Pakistan leaving auqāf in a miserable condition. For instance, in the absence of Mutawallis in Haryana all the waqf properties are directly managed by Waqf Board.

${ }^{14}$ Section $32(1)$

${ }^{15}$ Section $72(1)$

${ }^{16}$ Section $10(1)$

${ }^{17}$ Section $13(1)$

${ }^{18}$ Section 32 (1)

${ }^{19}$ Section 15

${ }^{20}$ Section 13 (2)-2(A)

${ }^{21}$ Section 13 (3)

${ }^{22}$ Section 14 (1)

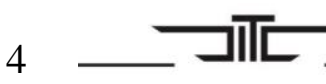

JOURNAL OF ISLAMIC THOUGHT AND CIVILIZATION 


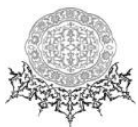

The Waqf Act provides for a full-time Chief Executive Officer of the Board, a Muslim by faith and appointed by the State Government from a panel of two names suggested by the Board and who shall not be below the rank of Deputy Secretary to the State Government and in case of non-availability of a Muslim officer of that rank, a Muslim officer of equivalent rank may be appointed on deputation. ${ }^{23}$

\subsection{Issues and Challenges of State Waqf Boards}

At present there are 32 Waqf Boards in India ${ }^{24}$ which are responsible for the general superintendence of respective auqāf in their States/Union Territories. There are some issues and challenges these Waqf Boards face while discharging their duties. ${ }^{25}$ Some of the main issues are stated below.

\subsubsection{Establishment of Waqf Board}

Waqf Act has empowered State governments to establish Waqf Boards. However, many State Governments have either failed to constitute the Board or have not appointed the full strength of the Board, which makes them non-functional. The State Governments have also shown apathy in appointing full time Chief Executive Officers. Since Chief Executive Officer discharges the directions of the Board and for practical purposes is the most important functionary, his/her absence breaks down the whole machinery. ${ }^{26}$ For political parties, Waqf Boards have become an opportunity for political patronage. Both the elected and appointed members have some political affiliation. In discharging their duties, political loyalties has often surpassed constitutional responsibilities. The recent controversies surrounding Delhi Waqf Board is a case in point. The Board was superseded by Delhi Government (Aam Admi Party hereafter AAP) under Section 99 (I) of the Waqf Act in October 2015. The incumbent Chairperson Rana Parween Siddiqui ${ }^{27}$ filed an appeal with High Court seeking to quash the notification and termed the action by AAP government as contempt of Court on the basis of an earlier status quo order. ${ }^{28}$ In March 2016 AAP MLA (Member of Legislative Assembly) was elected as the new

${ }^{23}$ Section $23(1)$

${ }^{24}$ Accessed on October 15, 2016,

http://wamsi.nic.in/wamsi/progress/WAMSI_MPR_SEP2016.pdf

${ }^{25}$ Section 32

${ }^{26}$ For details see Rajya Sabha, Ninth Report of Joint Parliamentary Committe on Waqf Parliamentary Report (New Delhi: Rajya sabha Secretariat, 2008), 33-37.

${ }^{27}$ She was elected as Chairperson on 20th January 2015 as the Congress Legislator Mateen Ahmad had resigned from his post as Waqf chairman before filing his nomination for Delhi Assembly Elections 2015.

28“AAP Government supersedes waqf board, strips it of powers." The Hindu, October 22, 2015,http://www.thehindu.com/news/cities/Delhi/aap-govt-supersedes-waqf-Board-strips-it-ofpowers/article7792666.ece 


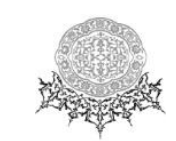

Chairman of the Board. ${ }^{29} \mathrm{He}$ was accused of alleged corruption and procedural irregularities and the Board was dissolved on 08 October 2016 and the case was referred to Central Bureau of Investigation for probe. ${ }^{30}$ The AAP government alleges that Board has been dissolved for fighting against corruption. ${ }^{31}$ This has made Waqf Boards unpopular and one of the main reasons why Muslims feel apathetic towards this institution. However, it does not imply that waqf in itself has ceased to be a thing of beauty and charm for Muslims. They feel associated with it and have time and again shown their concern regarding the current unsatisfactory condition of auqa $\bar{f}$.

\subsubsection{Survey}

For any activity on waqf properties, survey is pre-requisite as it will reveal the nature and potential of a given property. Such is the importance of survey that Joint Parliamentary Committee on Waqf in its ninth report described the survey chapter as the heart and soul of the Act. Section 4-8 of the Act provides for the appointment of Survey Commissioner and other additional or assistant commissioners as State Government feels necessary for the survey of auqāf in a State. The report prepared by Survey Commissioner has to be submitted to the State Government mentioning the number of Shia and Sunni waqfs in the State, the nature and objective of each waqf, gross income, land revenue, cesses, rates and taxes payable in respect of each waqf. Survey has to be completed within one year from the commencement of the Waqf Amendment Act, 2013 and Survey Commissioner has to be appointed within three months from such commencement in the cases where no such Survey Commissioner was appointed. The period for second or subsequent survey has been reduced to ten years. Earlier, the bar for second or subsequent survey was twenty years. The total cost of making a survey including the cost of publication of the list or lists of auqāf shall be borne by the State Government. Except Dadra and Nagar Haveli and Chandigarh Survey is yet to be completed. $^{32}$ The indifference of State Government in appointing Survey Commissioners and carrying out survey has paved the way for the large scale encroachment which waqf properties are facing.

\footnotetext{
29“"Okhla Legislator Elected Waqf Board Chairman,” Times of India, March 14, 2016, http://timesofindia.indiatimes.com/city/delhi/Okhla-legislator-elected-waqf-Boardchairman/articleshow/51386426.cms

30"L-G dissolves Delhi Waqf Board," The Hindu, October 8, 2016, http://www.thehindu.com/news/cities/Delhi/L-G-dissolves-Delhi-Waqf-Board/article15474523.ece

${ }^{31}$ Naveed Iqbal, "Removed by LG, former Waqf head and AAP MLA says "will go to court if necessary," The Indian Express, October 08, 2016, http://indianexpress.com/article/delhi/removedby-lg-former-waqf-head-and-aap-mla-says-will-go-to-court-if-necessary-3071562/

${ }^{32}$ Information collected personally from Central Waqf council on 18 February 2014.
} 


\section{-}

\subsubsection{Encroachment}

Joint Parliamentary Committee in its ninth report estimated that around 70 to 80 per cent of auqā $f$ has been illegally occupied. ${ }^{33}$ "Sachar Committee" observed two ways of encroachment; one is an absolute usurpation of property with no rents or other payments of any sort; and second is where the occupying party pays a nominal rent which has not been revised for decades. ${ }^{34}$ The disappointing thing is that state apparatus, which is supposed to be the custodian of waqf properties, is also involved in it.

As mentioned above waqf properties are under massive encroachment in entire country but the condition in north India especially in Punjab, Haryana and Delhi has been made worse by partition. There was an unprecedented mass migration of Muslims to Pakistan leaving behind huge properties including waqfs which were subsequently put under the control of custodians who allotted them to refugees/displaced persons mostly on the basis of possession. With the establishment of Waqf Boards under the Waqf Act, 1954 and the survey undertaken, a large number of waqf properties were found under illegal occupation. For recovering these properties the process of litigation was started but the suits were time barred. A special statute- the Public Waqfs (Extension of Limitation) Act, 1959 was passed and the period of limitation for filling of suits was extended up to $15^{\text {th }}$ August 1967 for all illegally occupied waqf properties dispossessed at any time after $14^{\text {th }}$ August 1947 and before $7^{\text {th }}$ May 1954. The date was e xtended several times and many properties were recovered. Since litigation is expensive and in the process the endowed property is drained up, Muslims have been demanding the extension of Public Premises (Eviction of Unauthorised Occupation) Act, 1958 to waqf properties but unfortunately this was not done. The much demanded and desired Waqf Properties (Eviction of Unauthorised Occupation) Bill, 2014 is pending in parliament. It is expected that the bill, if passed, will greatly help in removing the encroachment.

The provisions in Waqf legislation relating to the recovery of properties is not very effective; partly owing to the lack of will of law enforcement agencies and partly to the lack of necessary staff and funds required. Sections 51 to 56 of Waqf Act, 1995 deals with the important issues like prevention of alienation of waqf properties, their recovery, prohibition on purchase, removal of encroachment and restriction on lease. The most important section relating to removal of encroachment is section 54 which authorises the Chief Executive Officer (CEO) of Waqf Board to initiate action, suomoto or on application. The CEO has to follow the procedure demanded by the Act and can order the encroacher to vacate and deliver the possession of the property in question. The order passed under section 54 has to be

\footnotetext{
${ }^{33}$ Rajya Sabha, 2008: Qur'ān, al-Ma'idah 05:1.

${ }^{34}$ Government of India, Status of Muslim Community, 221.
} 


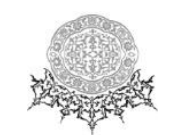

enforced through Sub-Divisional Magistrate under section 55 of the Act. By the end of 2014 in the National Capital Territory of Delhi alone 989 cases were pending with 17 concerned Sub-Divisional Magistrates for execution of removal of encroachment. ${ }^{35}$ In Maharashtra, 1088 orders were passed under section 54 by June 2007 and action was taken only in 21 cases. $^{36}$ Such indifference has frozen the process of eviction of encroachment and has made the waqf officials dispirited to pass more orders.

\subsubsection{Litigation}

The disputes regarding waqf properties as mentioned in section 6 (1) of the Waqf Act of 1995 essentially revolve around two questions. The first question is whether a property specified in the list of auqāf as waqf property is waqf or not? The second question is whether a waqf specified in the list is Shia or Sunni waqf? A suit in this regard may be filed with the Waqf Tribunal ${ }^{37}$ whose decision shall be final. However, a High Court suo motto or on the application can examine the case for legality or propriety and may confirm, reverse, or modify the order of the Tribunal as it may think fit.

The process of litigation is both expensive and time consuming. The State Waqf Boards are financially weak to afford an effective legal machinery to fight the cases. This has become a major impediment in the development of waqf properties. For the establishment of a strong legal cell, State Governments may provide necessary assistance to Waqf Boards as is available to other Government departments. ${ }^{38}$ Syed Khalid Rashid favours Alternative Dispute Resolution through negotiation, mediation, arbitration etc which will encourage out of court settlements, however, he cautions us not to take this route in serious matters involving ownership of waqf properties. ${ }^{39}$ Regarding properties under occupation of State, Joint Parliamentary Committee on Waqf recommended that such property be jointly developed and revenue proportionally shared by State Government and Waqf Board. ${ }^{40}$

\footnotetext{
${ }^{35}$ Information personally collected from Delhi Waqf Board on March 25, 2015

${ }^{36}$ Accessed October 16, 2016, http://www.mahawaqf.com/waqf-properties/

${ }^{37}$ Under Section 83 (1) of the Waqf Act 1995, "The State Government shall, by notification
} in the Official Gazette, constitute as many Tribunals as it may think fit, for the determination of any dispute, question or other matter relating to a waqf or waqf property, eviction of a tenant or determination of rights and obligations of the lessor and the lessee of such property, under this Act and define the local limits and jurisdiction of such Tribunals."

${ }^{38}$ Rajya Sabha, JPC on Waqf, para 7. 37.

${ }^{39}$ Syed Khalid Rashid, "Certain Legal and Administrative Measures for the Revival and Better Management of Awqāf July, 2011," Working Paper no.1432-02, (Jeddah: Islamic Research and Training Institute, 2014), 16.

${ }^{40}$ Rajya Sabha, JPC on Waqf, 116, para 7. 39. 


\section{.}

\subsubsection{Financial Problems}

The financial position of Waqf Boards is very weak. Under section 72 Waqf Boards annually receive contributions not exceeding $7 \%$ from mutawallis whose net annual income is not less than five thousand rupees. Such contribution is negligible since most of the auqāf are not yielding any income. Many Waqf Boards feel it extremely difficult to even pay the salaries to the staff. They are not in a position to fight cases in Courts and development of waqf properties is beyond their reach. It has been observed that some state governments have started giving grants to the board. The need is that all states should extend grant to the respective boards and it should be a handsome one, not a formality only. ${ }^{41}$

\subsubsection{Development}

Since waqf properties are heavilly encroached the emphasis of scholars and society has been on the preservation of waqf assets. However, there has been a shift from preservation to development in recent past. ${ }^{42}$ The development leads towards preservation of waqf properties by safeguarding both property and benefits of that property.

Section 32 (4) (5) (6) empowers Waqf Boards to develop a potential waqf property as an educational institute, shoping centre, market, housing or residential flats etc. For this purpose it may direct the mutawalli concerned to develop the property. If the Mutawalli fails either of reluctance or incompetance, the property can be taken over by the boarditself for development and will be returned to the Mutawalli after all expences incured by the board are recovered along with interest from the income of the property developed. However, given to the weak financial condition none of the Waqf Boards could effectively carry out the developmental programme.

The scheme for Development of Urban Waqf Properties of Central Waqf Council has been functioning for a long time now but limited financial resources has turned out to be the main obstacle in the much needed scheme for development of Waqf properties. Since its inception in 1974-75, a total Grant-in-Aid amounting of 4202.41 lacs has been realeased by Central Government to Central Waqf Council and the latter has extended loan to 136 projects out of which 85 have been completed and remaining are under construction. ${ }^{43}$ The grant released is no doubt commendable but it is too little to take up the huge task of development.

\footnotetext{
${ }^{41}$ See Rajya Sabha 2008 and recommendations of National Conference on 'Protection and Management of Waqfs' organized by Haryana Waqf Board from February 5-7, 2013 at Ambala.

${ }^{42}$ Mohammed Obaidullah, A Framework for Analysis of Islamic Endowment (Waqf) Laws. Working Paper no. 1435-15, (Jeddah: Islamic Research and Training Institute, October, 2014), 3.

${ }^{43}$ Annual Report and Audit Report of Central Waqf Council for the year 2013-2014, 9-12.
} 


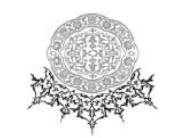

On the recommendations of Sachar Committee and Joint Parliamentary Committee on Waqf, National Waqf Development Corporation Limited (NAWADCO) was set up on $31^{\text {st }}$ December 2013 and was formally launched on $29^{\text {th }}$ January 2014 with the mission 'to act as nodal agency for development of viable Waqf properties transparently and professionally, so as to ensure enhancement of their income, for the benefit of the Muslim community, based on Islamic principles of Shari 'ah' and vision 'to provide technical, consultancy, managerial and financial support to Waqf management for increasing the productivity of Waqf properties.' 44 However, it is important to note that Rs 500 crores which is the authorised share capital of NAWADCO is less than $0.40 \%$ of market value of waqf properties as estimated by Sachar Committee at 1.2 lacs crores.

\subsubsection{Waqf Records}

Maintenance of waqf records is essential for the protection and preservation of auqāf. Almost all Waqf Boards have a record section for this purpose. Given to the poor infrastructure and old system of record keeping, the Joint Parliamentary Committee on Waqf, among other things, recommended computerization of the records of StateWaqf Board. As a result, the Waqf Management System of India (WAMSI) has been launched by the Ministry of Minority Affairs to streamline record keeping, introduce transparency, and to computerize the various functions and processes of the Waqf Boards and to develop a single web-based centralized software application. ${ }^{45}$ In this regard Ministry has given grants to all boards to set up the Centralised Computing Facility. Unfortunately, the process has been very slow on the part of Waqf Boards. The website uploads the progress report every month.

\section{Conclusion}

The paper attempted to explain the nature of waqf administration in India and the problems Waqf Boards are facing in discharging their duties. Before explaining the problem an attempt was made to explain the term waqf and the potential it has possesses. In addition, the brief evolution of waqf legislation and administration in India was also stated.

The focus was on the establishment of boards, survey, encroachment, litigation, financial issues, development and record keeping. It highlighted the problems in constituting the boards, lack of staff and the weak financial condition of Waqf Boards. The problems relating to the conduct of survey and removal of encroachment were also discussed. It was found that without a proper survey, no policy can be formulated as the knowledge about the exact number and nature of waqf properties will be murky and blurred. Since a huge number of waqf properties

\footnotetext{
${ }^{44}$ Accessed May 19, 2015, http://www.nawadco.co.in/vision_mission.php
}

${ }^{45}$ Accessed October 15, 2016, http://wamsi.nic.in/wamsi/base/aboutus.jsp 


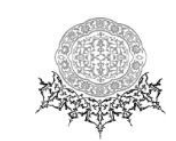

are under encroachment and the process to remove it has made it a cumbersome legal task, the preservation and development of waqf properties has become a distant dream. Furthermore, it was observed that the litigation process is cumbersome and costly, resulting in the drain of waqf income. The present unsatisfactory condition of waqf is more due to the cold approach of State Governments as they have remained silent spectators despite being aware of the misuse of waqf properties. The progress of digitalisation and computerization of Waqf properties under Waqf Management System of India (WAMSI) was also found to be very slow. One reason is that revenue records are not easily available. Therefore, State Government should direct district administration to provide the required information free of cost to the respective Waqf Boards. ${ }^{46}$ The WAMSI system serves as a novel way to check encroachments on auqāf with the help of GIS (geographical information system) and it will work as a deterrent for encroachers as the information is available in the public domain.

We are desperately lacking a cadre of professional waqf administrators and this can be addressed through the creation of Indian Waqf Services. For training of officers, National Waqf Academy may be established. Regular seminars and workshops should be organized by civil society to sensitize the people about auqāf. The imams can play an important role in educating the masses about the utility and

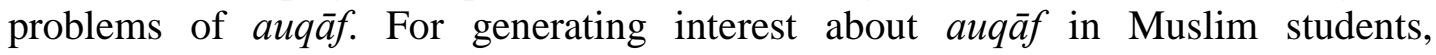
universities like Aligarh Muslim University and Jamia Millia Islamia may take initiative by introducing Waqf Studies as an optional paper in Social Sciences, Arts and Law Faculties.

\section{Bibliography}

Ahmed, Hasanuddin. and Ahmedullah Khan. Strategies to Develop Waqf Administration in India. Jeddah: Islamic Research and Training Institute, 1998.

Ahmed, Hilal. Muslim Political Discourse in Post-Colonial India: Monuments, Memory, Contestations. New Delhi: Routledge, 2014.

Government of India. Social, Economic and Educational Status of the Muslim Community of India Report. New Delhi: Cabinet Secretariat, 2006.

Haneef, Maulana Mufti Muhammad. "Waqf se Mutaliq Ahkam-o-Masai'l." [Rules and Regulations regarding Waqf, (Urdu)] In Auqāf: Ahkam-o-Masai'l. edited by Qazi Mujahidul Islam Qasmi. New Delhi: Ifa Publications, 2012.

\footnotetext{
${ }^{46}$ From the recommendations of National Conference on 'Protection and Management of Waqfs' organized by Haryana Waqf Board from February 5-7, 2013 at Ambala. Recommendation No 22.
} 


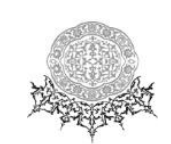

Kahf, Monzer. "Financing the Development of Auqāf Property." The American Journal of Islamic Social Sciences, Winter (1999): 39-66.

Kozlowski, Gregory C. Muslim Endowments and Society in British India. London: Cambridge University Press, 1985.

Obaidullah, Mohammed. A Framework for Analysis of Islamic Endowment (Waqf) Laws. Working Paper no. 1435-15. Jeddah: Islamic Research and Training Institute, October, 2014.

Qasmi, Qazi Mujahidul Islam. Auqāf: Ahkam-o-Masa'il. New Delhi. 2002. Reprint. Ifa Publications, 2012.

Rajya Sabha. Ninth Report of Joint Parliamentary Committe on Waqf. Parliamentary Report. New Delhi: Rajya sabha Secretariat, 2008.

Rashid, Syed Khalid. Awqāf Experiences in South Asia. 2002. New Delhi: Institute of Objective Studies, 2012.

Rashid, Syed Khalid. Certain Legal and Administrative Measures for the Revival and Better Management of Awqaf. Working Paper no. 1432-02, Jeddah: Islamic Research and Training Institute, July, 2011.

- Waqf Management in India: An Overview of the Past, Present and Future Administrative and Statutory Control on Auqāf. New Delhi: Institute of Objective Studies, 2006. 